\title{
THE DETERMINATION OF 4-METHYL-2-THIOURACIL IN ANIMAL BLOOD, URINE AND FAECES
}

\author{
by \\ K. VAN ASPEREN \\ Laboratory for Veterinary Physiology, University, Utrecht (Netherlands)
}

\section{INTRODUCTION}

Searching for methods for the determination of methylthiouracil in hen's blood, of which in most cases only small quantities are available, we had to simplify the methods described by VAN GENDEREN, VAN LIER AND DE Beus ${ }^{1}$. These methods often take up much time, which may be a serious disadvantage for many experiments. The method finally adopted proved to be sufficiently accurate for our purpose. In the determinations in plasma the precipitation of proteins was omitted; for total blood the precipitation procedure indicated by $\mathrm{CHESLEY}^{2}$ gave reliable results. Linkage of methylthiouracil with plasma proteins, which would interfere with these methods of determination, does not occur in our in vitro experiments and we do not believe it to be of great importance in the body.

The determination of methylthiouracil in human urine is very simple. Colorimetric determination of the green reaction product obtained by mixing a known amount of optically clear urine with GROTE's reagent, after adjustment of $\mathrm{pH}_{\mathrm{H}}$ to about 8.0, gives good results. As small differences in procedure may have great influence we propose to give a detailed description of the method in this paper.

Greater difficulties are encountered in determining methylthiouracil in hen's urine, as in these animals urine and faeces are mixed before leaving the body. We therefore determined methylthiouracil in the mixture of urine and faeces and tried to differentiate between urine and faeces in another way. As a number of disturbing factors proved to be present in this mixture a simple extraction-procedure did not suffice, but we obtained very good results by dialysing the mixture of faeces and urine at slightly acid reaction. We shall describe this method below.

All determinations were carried out with GroTE's reagent, prepared according to the prescription of $\mathrm{M} \varnothing \mathrm{RCH}^{3}$. By adding of boric acid-borax buffer the $\mathrm{pH}$ of the reaction mixture was adjusted to $7.5-8.5$ and the absorption of light by the green-coloured solution was measured with the aid of a photoelectric colorimeter with a dark-red filter.

\section{EXPERIMENTAL}

\section{Grote's reagent}

The preparation of the reagent was based on the prescription given by Mørch. As, however, details may be of great importance, we shall describe the method, as used by us. I gram of sodium nitroprusside and $\mathrm{I} g$ of hydroxylamine hydrochloride were dissolved in $20 \mathrm{ml}$ of distilled water and 
$2 \mathrm{~g}$ of sodium bicarbonate were added in small portions. The solution was shaken until the fizzing stopped. Thereupon o.I $\mathrm{ml}$ of bromine was added and the solution was again shaken for about 5 minutes. Then the solution was filtered into a volumetric flask and diluted with distilled water to $50 \mathrm{ml}$. The reagent was distinctly brown at first, but after a short time a yellow precipitate appeared on the bottom of the flask. Sometimes this precipitate was removed by filtration, but this proved to be unnecessary if care was taken not to include any precipitate in the solution used for the colorimetric reaction. The differences between one batch of reagent and another one proved to be only small. If the reagent was kept in refrigerator it could be used for several weeks, but during that time the light extinction of the colour, developed with a standard solution of methylthiouracil, decreased gradually. For these reasons we thought it necessary to run an experiment with a standard solution at least once every two days.

\section{The determination in plasma or serum without precipitation of proteins}

The determination of methylthiouracil in the serum of horses and cattle may be carried out as follows: to $0.5 \mathrm{ml}$ of serum are added $5.1 \mathrm{ml}$ of borax buffer and $0.4 \mathrm{ml}$ of GROrE's reagent. About 15 minutes after adding the reagent the light absorption by the green-coloured reaction mixture is measured and compared to the absorption of a standard solution of methylthiouracil in distilled water. It is necessary to subtract the extinction value, obtained with a sample of serum containing no methylthiouracil (serum blank). This value, however, is fairly small and constant. As the reaction velocity decreases with increasing age of the reagent, it may be recommended to determine the extinction at different times, choosing the maximal extinction value for calculation.

A few examples of determinations are given in Table $\mathbf{I}$.

\section{TABLE I}

\section{RECOVERY OF ADDED METHYLTHIOURACIL}

$\mathrm{E}$ is the extinction coefficient ${ }^{\star}=1 / 2 \log 100 / I$, in which $I$ is the intensity of the light transmitted by the sample in percentage of the original intensity.

mtu-serum = serum containing Io $\mathrm{mg}$ pCt methylthiouracil.

\begin{tabular}{l|c|c|c|c|c|c|c}
\hline & mtu-serum & $\begin{array}{l}\text { serum } \\
\text { blank }\end{array}$ & E-blank & $\begin{array}{c}\text { standard } \\
\text { Io mg pCt }\end{array}$ & $\begin{array}{c}\text { reagent } \\
\text { blank }\end{array}$ & E-blank & Recovery \\
\hline Horse & 0.121 & 0.020 & 0.101 & 0.118 & 0.010 & 0.108 & $94 \mathrm{pCt}$ \\
Horse & 0.116 & 0.014 & 0.102 & 0.117 & 0.005 & 0.112 & 91 pCt \\
Horse & 0.128 & 0.013 & 0.115 & 0.127 & 0.005 & 0.122 & 94 pCt \\
Cow & 0.120 & 0.016 & 0.104 & 0.118 & 0.003 & 0.115 & 90 pCt \\
\hline
\end{tabular}

* The extinction $=\log$ Ioo $/ I$ is divided by 2 , as a cell of $2 \mathrm{~cm}$ width is used.

Several experiments showed that the extinction-concentration diagram is in accordance with the law of BEER-LAMBERT for concentrations ranging from I to $40 \mathrm{mg} \mathrm{pCt}$. So the conclusion seems justified that recovery in this range of concentrations is about 90-95 pCt. At low concentrations, however, the uncertainty pertaining to the serum blank values may form a serious difficulty when determining methylthiouracil in plasma or serum.

The determination of methylthiouracil in hen's plasma meets with some technical difficulties:

a. The amount of plasma available is rather small, especially when several determinations have to be performed on the same animal at short intervals. In many cases we only had I $\mathrm{ml}$ of plasma at our disposal. 
b. After the addition of the reagent the mixture sometimes becomes turbid, rendering colorimetric estimation impossible.

c. The estimations obtained with plasma blanks are rather high and vary to some extent.

When precipitation of the proteins is omitted only $0.5 \mathrm{ml}$ plasma is required, so the first difficulty may be easily overcome.

In most cases the turbidity appearing after addition of GROTE's reagent can be removed by gently heating the reaction-mixture. When the plasma is perfectly clear this turbidity is never formed and heating is not necessary. One should take into account the increase of the reaction velocity when heat is applied.

- The third difficulty introduces a rather large uncertainty. The extinction of the plasma blank is about 0.107 with clear yellow plasma (employing a $2 \mathrm{~cm}$ cell). In some cases, however, especially in cases of slight haemolysis, higher values up to 0.132 are obtained. The difference between this maximal value (o.r32) and the normal value (0.107) means a difference of $4 \gamma$ per $0.5 \mathrm{ml}$ of plasma or $0.8 \mathrm{mg} \mathrm{pCt}$. When 0.107 is used as blank value for calculating the concentration in the plasma, a deviation from the real concentration may be expected. This deviation may amount to maximally $0.8 \mathrm{mg} \mathrm{pCt}$, but generally, and certainly when there has been no haemolysis and the plasma is perfectly clear, it is much smaller.

The recovery values obtained with this method after addition of methylthiouracil in amounts varying from $\mathrm{I} .7 \mathrm{mg} \mathrm{pCt}$ to $\mathrm{I} 2 \mathrm{mg} \mathrm{pCt}$, range from 88 to $\mathrm{I20} \mathrm{pCt}$, averageing I00 $\pm 9 \mathrm{pCt}$. Here too the extinction was found to obey the law of Beer-Lambert.

\section{The determination in serum with Chesley's precipitation method}

The proteins are precipitated with a freshly prepared mixture of equal parts of Io $\mathrm{pCt}$ sodium tungstate and $2 / 3 N$ sulphuric acid. Equal amounts of this mixture and serum are mixed in a centrifuge tube. The tube is shaken vigorously and then centrifuged. To I $\mathrm{ml}$ of the clear supernatant fluid are added $4.6 \mathrm{ml}$ of borax buffer and $0.4 \mathrm{ml}$ of GROTE's reagent. Maximal extinction is measured and compared with that of a standard solution. The serum blank values obtained with this method are negligibly small. When ro $\mathrm{mg}$ of methylthiouracil was added to $100 \mathrm{ml}$ of serum $99 \mathrm{pCt}$ was recovered (two determinations).

\section{The determination in blood with Chesley's precipitation method.}

To $5 \mathrm{ml}$ of blood $5 \mathrm{ml}$ of distilled water are added. When haemolysis has occurred equal amounts of the haemolysed blood and the tungstate-sulphuric acid mixture are mixed and shaken in a centrifuge tube. After centrifuging I or $2 \mathrm{ml}$ of the supernatant fluid is used for the colorimetric determination with GROTE's reagent as described above. Of ro $\mathrm{mg} \mathrm{pCt}$ and $20 \mathrm{mg}$ pCt methylthiouracil added to the blood, 90 and roo pCt were recovered respectively. It was shown, moreover, that for concentrations ranging from 4 to $20 \mathrm{mg}$ pCt the extinction-concentration diagram is in reasonable accordance with the law of BEER-LAMBERT. This method is certainly not as exact as that described by VAN Genderen, VAN LIER AND DE BeUs' ${ }^{1}$, but it requires less time and only a small quantity of blood. Perhaps $2 \mathrm{ml}$ of blood will be sufficient. With low concentrations we think it better to use the extraction procedure described by the authors mentioned above. 


\section{The determination in human urine}

After collection the urine was adjusted to $\mathrm{pH}=$ about 8 and then centrifuged or filtered to obtain an optically clear solution. To $\mathrm{I} .0 \mathrm{ml}$ of urine were then added $5.0 \mathrm{ml}$ of borax buffer or, in a number of cases, $4 \mathrm{ml}$ of borax buffer and I $\mathrm{ml}$ of ethanol. After addition of $0.4 \mathrm{ml}$ of GRoTE's reagent the light absorption was measured at regular intervals. Of ro $\mathrm{mg} \mathrm{pCt}$ methylthiouracil added to the urine, $80-85 \mathrm{pCt}$ was recovered.

When determining methylthiouracil in human urine one should take into account this rather low recovery and also the uncertainty in the urine-blank value, which proved to be rather high in our experiments (extinction $=$ about 0.100 with a $2 \mathrm{~cm}$ cell). Determination in the urine of cattle failed to give good results, as brown coloured reaction products prevented measurement of the light absorption.

\section{The determination of methylthiouracil in hen's excreta}

For reasons of simplicity we shall designate the urine-faeces mixture as "excreta", notwithstanding this term is not quite correct theoretically. The determination of methylthiouracil in hen's excreta meets with great difficulties as a number of substances are present which disturb the colorimetric reaction with GROTE's reagent. Extinction procedures only gave bad results but dialysis of the excreta at slightly acid reaction (we do not know whether this acid reaction is absolutely necessary) yielded a very good recovery of added methylthiouracil in a large number of cases.

The dialysis was carried out with the aid of the simple apparatus shown in Fig. I.

A dialysis bag of a capacity of about 50 to $60 \mathrm{ml}$ was obtained by fixing a cellophane tube $(t)$ around the lower end of a glass tube $(\mathrm{g})$ of a diameter of $30 \mathrm{~mm}$. The cellophane tube is closed by inserting a small piece of a glass tube of about the same diameter. This last tube $(b)$ is annealed to form the bottom of the dialysis bag. The cellophane is tied up with a thin cord $(c)$ under the tube $b$ to prevent leakage of fluid from the dialysis bag. A glass rod $(r)$ moving up and down through a hole in the stopper (s) that fits the neck of the glass tube $g$, assures good stirring of the fluid inside the dialysis bag.

Now Io $g$ of excreta are ground in a mortar with sand and

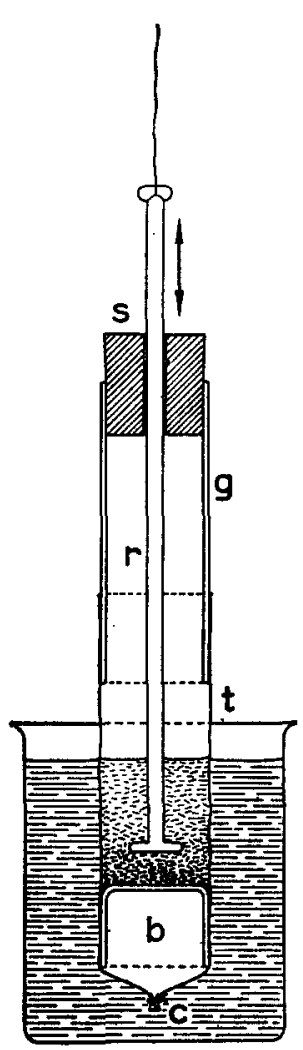

Fig. I $30 \mathrm{ml}$ of $\mathrm{N} / \mathrm{ro}, 000 \mathrm{HCl}$ are added. The suspension of excreta is poured into the dialysis bag and a beaker containing 150 to $200 \mathrm{ml}$ of $\mathrm{N} / \mathrm{IO}, 000 \mathrm{HCl}$ is placed around this bag. Care is taken that the fluids inside and outside the bag are at about the same level. Dialysis was continued for 12 to 24 hours at room temperature. During this time an equal distribution of methylthiouracil is obtained over the fluids inside and outside the bag and determination of methylthiouracil in the outer fluid with the aid of GROTE's reagent makes it possible to calculate the concentration of this substance in the excreta.

To $4 \mathrm{ml}$ of the outer fluid $\mathrm{I} \mathrm{ml}$ of borax-buffer and $\mathrm{I} \mathrm{ml}$ of ethanol are added. The fluids are mixed, $0.4 \mathrm{ml}$ of GROTE's reagent is added and maximal extinction is measured and compared with the maximal extinction given by a $2 \mathrm{mg} \mathrm{pCt}$ methyl- 
thiouracil standard solution. By adding ethanol the colour is stabilized and the recovery is markedly improved. Sometimes, however, the addition of ethanol causes a faint opacity. In most cases, therefore, we added $2 \mathrm{ml}$ of borax buffer and $2 \mathrm{ml}$ of ethanol to $8 \mathrm{ml}$ of the fluid, mixed and filtered the solution through a hard filter. To $6 \mathrm{ml}$ of the filtrate $0.4 \mathrm{ml}$ of reagent is added, etc.

Blank determinations in excreta without methylthiouracil give extinctions of about 0.090 (with a $2 \mathrm{~cm}$ cell). This blank value is rather high but remarkably constant. The extinction given by the outer fluid without reagent is only small.

If $4 \mathrm{mg}$ methylthiouracil were added to Io $\mathrm{g}$ of excreta the recovery values in a number of cases were I01, 99, I02, 99, I04, I02, I02, 96, I00, I02 and 92\%, averageing $100 \%$. The extinction-concentration diagram proved to be in full accordance with the law of BEER-LAMBERT over a wide range.

\section{SUMMARY}

A method is described for the determination of 4-methyl-2-thiouracil in blood, human urine and hen's excreta. In the determination in the excreta a suspension of these excreta is dialysed for r2-24 hours against acid water and the determination is carried out in this acid water, as always with the aid of GROTE's reagent.

This method was applied with good results in later studies on the metabolism of methylthiouracil in poultry.

\section{RÉSUMÉ}

Description d'une méthode pour le dosage du 4-méthyl-2-thiouracile dans le sang, l'urine humaine et les excréments de poule. Pour le dosage dans les excréments une suspension des excréments est dialysé pendant I2 à $_{24}$ heures contre de l'eau acide et le dosage colorimétrique dans l'eau acide est fait, comme toujours, au moyen du réactif de GroTr.

\section{ZUSAMMENFASSUNG}

Eine Methode zur Bestimmung von 4-Methyl-2-Thiouracil in Blut, Harn und Kot wird gegeben. Zur Bestimmung in Hühnerkot wird eine Suspension von den Exkrementen während 12 bis 24 Stunden gegen saures Wasser dialysiert und nachher der Gehalt an Methylthiouracil in der Aussenflüssigkeit bestimmt. Für die Dialyse wird “Cellophan"-Dialysierschlauch benutzt, für die kolorimetrische Bestimmung gebrauchen wir GroTE's Reagenz.

\section{REFERENCES}

1 H. van Genderen, K. L. Van Lier, ANd J. DE Beus, Biochim. Biophys. Acta, 2 (1948) 482.

L. C. ChesLey, J. Biol. Chem., 152 (1944) 571 .

3 P. Mørch, Acta Pharmacol. Toxicol., I (1945) Io6. 